\title{
The Impact of NEET and Labor Market Indicators on Human Development: A Panel Data Analysis for EU-28 Countries
}

\author{
Ufuk Bingöl' ${ }^{10}$, Fatih Ayhan² ${ }^{(1)}$
}

\begin{abstract}
This study aims to investigate the effect of education, unemployment and not-in-education employment or training (NEET) population on human development in the EU-28 countries during the 2004-2018 period by using panel data analysis. According to the panel data analysis results with Common Correlated Effects Mean Group (CCEMG) estimator, the variables unemployment (UNE) and education (EDU) are statistically significant in explaining Human Development Index (HDI) across the panel. In contrast, the variable NEET is found to be not statistically significant, but the obtained coefficient is in the expected direction. In this case, a $1 \%$ increase in the UNE variable decreases $\mathrm{HDI}$ by $0.01 \%$, and a $1 \%$ increase in the EDU variable increases HDI by $0.30 \%$. The model appears to be statistically significant. According to the regression estimation results based on for each country, the coefficients vary quantitatively and statistically. Still, it is noteworthy that the NEET variable, which is statistically insignificant throughout the panel, varies statistically from unit to unit. These results confirm that NEET and HDI are negatively correlated in Czechia, Denmark, Finland, and Germany, while positively correlated in France, Poland, and Portugal.
\end{abstract}

\section{Keywords}

Human Development, Neet, Unemployment, Panel data analysis

JEL Classifications: E24, O15, C23

1 Corresponding author: Ufuk Bingöl (Asst. Prof. Dr.), Bandırma Onyedi Eylül University, Manyas Vocational School, Department of Management and Organization, Balıkesir, Turkey. E-mail: ubingol@bandirma.edu.tr, ORCID: 0000-00031834-842X

2 Fatih Ayhan (Assoc. Prof. Dr.), Bandirma Onyedi Eylül University, Faculty of Economics and Administrative Sciences, Department of Economics, Balıkesir, Turkey. E-mail: HYPERLINK “mailto:fayhan@bandirma.edu.tr” fayhan@bandirma. edu.tr ORCID: 0000-0002-7447-5506

To cite this article: Bingol, U., \& Ayhan, F. (2020). The Impact of NEET and Labor Market Indicators on Human Development: A Panel Data Analysis for EU-28 Countries. Sosyal Siyaset Konferansları Dergisi, 79, 441-468. https://doi.org/10.26650/ jspc.2020.79.0158 


\section{Introduction}

The economic policies of countries differ according to development criteria in line with their growth and development goals. In this sense, the development potentials of countries have been measured with monetary criteria since the mid-twentieth century in determining their economic growth. However, this reliance on monetary criteria for determining economic growth and development neglects the socio-economic parameters of countries, such as capacity utilization, access to education and health services, quality of life, and sustainability. These socio-economic parameters are measured with the "Human Development Index (HDI)" in Human Development Reports created by the United Nations Development Program (UNDP) annually since 1990. Currently, UNDP measures the HDI of 189 countries. (UNDP, 2019). HDI is an index that allows the measurement of essential components of social policy such as education, health, as well as per capita income, which is aimed to increase the welfare level of the society. However, according to the literature, there are some deficiencies in the content of HDI since the employment structure as well as the unemployment issues and parameters should also be considered essential indicators of the countries' socio-economic development besides the HDI (Taner et al., 2011). In addition to the unemployment problem in the world, especially in developing countries, the impact of the population that is not in education or employment linked to the unemployment problem on economic development emerges as a notable field worth studying. Long-term unemployment and NEET status especially have severe consequences for economic growth and development (Quintano et.al., 2018). The primary motivation of this study is to examine the relationship between unemployment, NEET, and HDI. In this context, it will be useful to examine the relationship between HDI, unemployment, NEET, and education in the EU member countries, which have completed the economic and monetary union process and are the most successful group in terms of economic integration today. The reason for this analysis being based specifically on the EU member countries is that it is a prosperous area on the way to economic integration and because it has a heterogeneous structure of countries from different levels of development, it has the potential to create an infrastructure in order to generalise the analysis results. For this purpose, the HDI, unemployment, and NEET data and the World Bank Education index data of the 28 EU member countries between the years 2004-2018 have been analyzed wih the panel data analysis method. 
This study consists of three parts. The first part presents a conceptual framework on human development, unemployment, and NEET. The second part examines the literature within the scope of the study. The third part shares the findings of the study conducted with econometric methods. Subsequently, the study will be completed with an evaluation of the findings in the conclusion section.

\section{Conceptual Framework}

\section{Human Development Index}

Approaches from the past to present that link human development with economic growth has been insufficient in increasing prosperity, solving poverty, and other social problems. From this point onwards, many scientists and international institutions have been trying to create critical indicators of the societies' social development by measuring human welfare since the 1960s (Stanton, 2007). The United Nations (UN) Social Development Research Institute published the "The Level of Living Index," in 1966, which was limited to 20 countries under the categories of basic physical, cultural, and luxury needs, followed by "The Development Index" in 1972, which included nine social and economic indicators. In the same year, OECD developed the "Estimated GNP Per Capita Index" with five social indicators for 82 developing countries. In 1975, the UN Economic and Social Council prepared a report for 140 countries consisting of two social indicators, literacy and expected lifetimes; and five economic indicators, energy, GDP production share, export production share, number of telephones, and non-agricultural employment. In 1976, the International Labour Organization (ILO) started to prepare a report within the scope of the basic needs approach in development. In 1979, the Overseas Development Council developed the "Physical Quality Index of Life" for monitoring progress in health, hygiene, education, and women's status, which included expected life expectancy, infant mortality and literacy rates as well as including GDP, whose output was however not measured (Morris, 1979). To complement the missing points of this index in quality of life measurement, Camp and Speidel (1987) developed and published the Human Suffering Index, which includes social indicators such as access clean drinking water, energy consumption, the number of calories that people need to take daily and so on, in addition to economic growth indicators such as urban population growth, increase in labor force participation rate and so forth (Kelley, 1989). 
In addition to the indices mentioned above, the IMF and World Bank's budget management, which has been supporting developing countries to manage the costs of structural arrangements for human development since the 1980s, was influential on growth, but its effect on problems such as the HIV/AIDS epidemic period, the increase of crime rates, environmental pollution etc. was very low (Haq, 1995). With the idea that the increase in income per capita is not enough to measure human development alone, Mahbub ul Haq submitted a proposal to create a human development report to UNDP in Spring 1989. In May 1990, the first human development report was published by the Oxford University Press, which included concept and measurement method and examined the relationship between economic growth and human development. Following this development, The Human Development Report and HDI had been published annually under various themes. Finally, in 2019, the Human Development Report for 189 countries was published with the theme "Beyond income, beyond averages, beyond today: Inequalities in human development in the 21 st century" (UNDP, 2019). Various changes have occurred in index calculations since the date of its first publication due to the emergence of new data and methods that can be added to the elements forming the HDI (Uğur, 2017). These changes are shown in Table 1.

Table 1

Calculation Dimensions and Indicators of HDI (Source: UNDP, 2009; 2010; 2019)

\begin{tabular}{|c|c|c|c|}
\hline \multicolumn{4}{|c|}{ 1990-2009 } \\
\hline Dimensions & Indices & Min. & Max. \\
\hline Long and Healthy Life & Life expectancy at birth (Year) & 25 & 85 \\
\hline \multirow{2}{*}{ Knowledge (Education) } & Adult Literacy $(\%)$ & 0 & 100 \\
\hline & Gross Enrolment Ratio (\%) & 0 & 100 \\
\hline A Decent Standard of Living & $\mathrm{GDP}(\mathrm{PPP}, \$)$ & 100 & 40.000 \\
\hline Combination & \multicolumn{3}{|c|}{ ARITHMETIC MEAN } \\
\hline \multicolumn{4}{|c|}{$2010-2019$} \\
\hline Dimensions & Indices & Min. & Max. \\
\hline Long and Healty Life & Life expectancy at birth (Year) & 20 & 83,2 \\
\hline \multirow{2}{*}{ Knowledge (Education) } & Expected years of schooling & 0 & 20,6 \\
\hline & Mean years of schooling & 0 & 13,2 \\
\hline A Decent Standard of Living & GNI $(P P P, \$)$ & $100 *$ & $75000 *$ \\
\hline Combination & \multicolumn{3}{|c|}{ GEOMETRIC MEAN } \\
\hline
\end{tabular}

*Values can vary according to highest countries

There are three criteria in the HDI regarding the current calculation method: long and healthy life, knowledge, and a decent standard of living. Under these three criteria, the sources of the indices are shown in Table 2. 
Table 2

HDI Indices' Data Source(s) (Source: UNDP; 2019)

\begin{tabular}{lc}
\hline Indices & Source(s) \\
\hline Life Expectancy at Birth & UNDESA \\
Expected Years of Schooling & UNESCO \\
& ICF Macro Demographic and Health Surveys \\
UNICEF Multiple Indicator Cluster Survey & OECD \\
Mean Years of Schooling & UNESCO Statistic Institute \\
& Access to Education Dataset (Barro \& Lee (2018)) \\
ICF Macro Demographic and Health Surveys UNICEF & Multiple Indicattor Cluster Surveys OECD \\
GNI Per Capita & World Bank \\
& IMF \\
& United Nations Statistic Division \\
\hline
\end{tabular}

HDI is calculated in two steps. In the first step, dimension indices are calculated. In the creation of dimension indices, as shown in the formula below, the ratio of the difference between the actual indicator value and the lowest indicator value of the relevant country to the difference between the highest indicator value and the lowest country indicator value is calculated (UNDP, 2019).

$$
\text { Dimension Index }=\frac{\text { Actual Value }- \text { Minimum Value }}{\text { Maximum Value }- \text { Minimum Value }}
$$

In the second step, the HDI is calculated according to the following formula by taking the geometric mean of the indices of the relevant dimensions (UNDP, 2019):

$$
\mathrm{HDI}=\left(I_{\text {Health }} \cdot I_{\text {Education }} \cdot I_{\text {Income }}\right)^{1 / 3}
$$

The HDI value calculated above is expected to be between 0 and 1 . In this context, since 2014, fixed achievement categories have been determined for human development values according to these values (UNDP, 2019). Determined fixed achievement categories are presented in Table 3:

Table 3

Human Development Categories (Source: UNDP; 2019)

\begin{tabular}{lc}
\hline Definition & Values \\
\hline Very high human development & 0.800 and above \\
High human development & $0.700-0.799$ \\
Medium human development & $0.550-0.699$ \\
Low human development & Below 0.550 \\
\hline
\end{tabular}


The HDI values of EU 28 countries calculated by UNDP by years are shown in Figure 1 below:

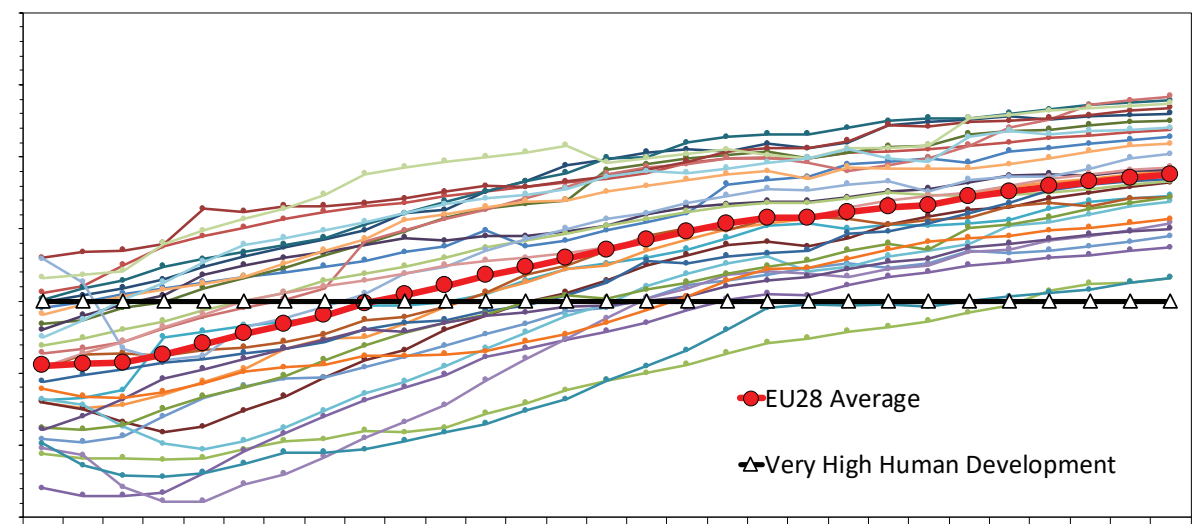

Figure 1. HDI Scores of EU28 Countries according to Years (Source: UNDP; 2019)

As shown in Figure 1, it is noteworthy that the index scores of all $28 \mathrm{EU}$ countries have a rising trend since the year HDI was first published. After 2014, all EU countries are found in the Very High Human Development category. Furthermore, there are thirteen countries (Bulgaria, Croatia, Greek Administration of Southern Cyprus (G.A.S.C.), Estonia, Greece, Hungary, Italy, Latvia, Malta, Poland, Portugal, Romania, and Slovakia) that have not yet reached the EU28 average.

\section{Relationship between HDI, Unemployment, NEET and Education}

Various criticism has emerged over the years that the HDI, which had emerged initially as a result of the criticisms directed to the approaches that relate socio-economic development to growth, is insufficient to cover all aspects of development (e.g. Aturupane et al., 1994; Kelley, 1989; Morris, 1979). Taking these critics' points into consideration, new indices were developed with the HDI in the following periods. In this context, the development process started with the Human Poverty Index, and continued on with indices such as Multidimensional Poverty Index: Developing countries, Inequality-adjusted Human Development Index, Gender Development Index, Gender Inequality Indices. In order to understand the impact of poverty on human development, the Human Development Index 
(HDI) developed by the UNDP based on the capability approach of Amartya Sen (1999) should be examined in terms of the transformation into incomecapability deficiency. As a result of this transformation, the negative effect that the labour income loss the majority of the society experiences has on welfare because of the unemployment problem is taken into consideration at a very limited scale in the above-mentioned indices. At this point, it should be remembered that, depending on the development level of the countries (i.e. developed and developing countries) as well as the education level of the workforce, employment contributes positively to human development with its anti-poverty effect (Karnani, 2011). Proper orientation of the workforce, especially for the youth starting with their education, is significant for the development of the country and the social increase of the human capital. For example, individuals who participate in the workforce can gain new skills by improving their existing qualifications after being included in the work-life. Consequently, from the view of the human capital perspective, a high education level is a tool of human development and the most important goal of the development process as well as the employability benefit (FloresCrespo, 2007). Education and skills is one of the basic criteria for individuals to obtain better living conditions. The educated workforce concept is important for individuals for better job conditions, higher income, and non-economic social actions. In this sense, education level and welfare are in direct relation. A high level of education leads to increased welfare.

Various suggestions have been presented to this day to improve the accuracy while measuring human development, such as the inclusion of the workforce employment level and the unemployment level as the index's sub-dimensions and indicators (Taner et al., 2011). However, while education indicators are still included in HDI, unemployment, and employment criteria are not yet included in the index. OECD measures human development for member countries with 11 welfare criteria, including employment and unemployment indicators in the content of Better Life Index published since 2011 (OECD, 2014). Another important dimension of human development and its relation to human capital is the position of youth in labour markets. A negative impact of staying away from labour markets and education due to various reasons regarding the individuals' personal capital formation is that it limits the human capital development and employability indirectly (Côté, 1997 in Bynner \& Parsons, 2002). 


\section{Literature Review}

Many studies in the literature examine the relationship between economic growth and human development from various aspects. In these studies, it was observed that the effect of economic growth on human development depends on various factors including labor markets indicator's impact, but it has a predominantly positive effect.

Aturupane et al. (1994) explained the relationship between poverty, human development, and economic growth with cross-country data, the logistic regression method, and examples from the countries Sri Lanka and Pakistan. It was determined that income growth is not the leading parameter when it comes to improvements to human development social indicators.

Ranis et al. (2000) analyzed the relationship between economic growth and human development in developing countries between the years 1960-1992 using the OLS regression method. The analysis results showed that there was a necessary but insufficient and repetitive process between the improvement of human development and economic growth. In light of these findings, they concluded that economic growth would not be sustainable without efforts to increase human development.

Suri et al. (2010) analyzed the relationship between sustainable economic growth and human development using the panel data method. The analysis revealed the necessity of implementing successful policies not only for the impact of human development on economic growth, but also for sustainable growth.

Ulaş and Keskin (2017) analyzed the relationship between human development and economic performance by using AHP and TOPSIS multi-criteria decisionmaking methods on the data from 20 European countries between the years 2000-2014. The analysis showed a positive effect in line with the current literature.

Aydin (2019) examined the relationship between human development and economic growth in Turkey between the years 1990 to 2017 using ARDL and Panel Bootstrap causality method. According to the results, there is bidirectional causality between human development and economic growth in Turkey and these two variables were observed to move together in the long term. 
Balc1 and Özcan (2019) analyzed the relationship between human development and economic growth by using the panel data analysis method on the OIC countries' data from 2005 to 2017 . The results showed a positive relationship between human development and growth in the OIC countries. The same study concluded that there was a significant relationship between the variables in the long run, and both variables were positively related to each other.

Erdem and Çelik (2019) analyzed the relationship between human development and economic growth with the ARDL method, using data from 33 African countries between the years 1995-2014. The results showed a positive effect between the income indices of human development index and economic growth in the short term, but an adverse effect between education and health indices and the economic growth. However, in the long-term overall analysis, a positive effect was observed in general, supporting the current literature.

Another area that has been examined through a variety of methods is the relationship between human development and employment and unemployment. For instance, Feng et al. (2018) analyzed the relationship between unemployment and development using data from household surveys of 84 countries between 1960 and 2015, relying more on the data from 1990-2000, using panel data analysis. The analysis showed that the unemployment rates of people with lower or no education in developed countries have a positive effect on the GDP.

Taner et al. (2011) proposed an alternative HDI as the current HDI indicators do not include the employment and unemployment dimensions of human development. A comparison of the proposed index and the current index was conducted with the data of from OECD countries between the years 1998-2010 and the correlation analysis method. Accordingly, it is stated that the scores of countries such as Australia, Canada, Sweden, Germany, and Ireland were overestimated according to the current HDI. Conversely, it was observed that the scores of Switzerland, Japan, South Korea, and Denmark were underestimated because unemployment indicators were not included.

Zanbak and Kartal (2019) examined human development and female unemployment in BRICS countries between the years 1991-2017 with the panel ARDL method. According to the results of the analysis, a 10\% decline in female unemployment rate increased human development by $4 \%$. 
Flores-Crespo's (2007) qualitative study examines the situation in Mexico in terms of education, employment, and human development according to Sen's (1999) capability approach in human development. According to the results of the analysis, while the technical higher education institutions in the poorer regions of Mexico have regional human capital and employment-enhancing features, the absence of different social and economic opportunities in the same region negatively affected regional human development.

Utilising descriptive methods, Hull (2009) examines the relationship between economic growth, unemployment, and increasing human development in order to decrease poverty. Hull (2009) proposes to conduct production-intensive or employment-intensive sector analyses by following the sectoral pattern of growth. It is stated that both conditions have an effect on poverty reduction. A quantitative and qualitative analysis that include socioeconomic factors is proposed in order to measure the growth contribution of employees with lower income status, who are in sectoral employment.

The relationship between human capital and human development is also frequently examined in the literature. For instance, Keskin (2011) examined the relationship between the human capital and economic development data from 177 member countries of the $\mathrm{UN}$ and using the linear regression method. According to the results of the analysis, the rate of literacy, education level, public health expenditures, and $R \& D$ expenditures have a positive effect on economic development.

Quintano et al. (2018) analyzed the impact of the economic crises on the factors affecting the NEET including the human capital elements in Italy, in a bivariate probit model. They concluded that there was a need for redesigning the vocational and non-formal education models according to the needs of the labour markets in the transition from education to work.

When empirical studies on the subject are evaluated in general, it is seen that studies are mainly concentrated on the relationship between HDI and growth. It has been demonstrated that growth and HDI variables are generally positively related. Furthermore, in studies where the relationship between education and HDI is examined, it is seen that the increase in education positively affects the HDI and that the increase in education level will bring increases in employment. 
In terms of sustainable growth and human development, unemployment and especially NEET issues that states face should be included to the literature as essential topics to discuss. The fact that human development is mostly associated with economic growth, according to the relevant literature, has led to the ignoring of labor market indicators, which are expected to have a positive effect on both variables. Against this backdrop, the contribution of this study to the literature and its difference from previous studies is that the relationship between HDI, NEET, unemployment, and education was handled for the first time among the studies carried out within literature. Thus, the study aims to determine how the change in education, unemployment, and NEET affect HDI and welfare. The analysis of heterogeneous country groups such as the EU-28 will allow for a better generalization on global scale in the short term and will provide a smooth kick-start in addressing human development-labor market relationships.

\section{Data And Methodology}

\section{Data}

The education index, NEET (\%), unemployment (\%) and HDI index data for the current study were retrieved from the UNDP database, and were used for the EU-28 country group in Table 4 . The definitions of data are represented in Table 4.

Table 4

EU-28 Countries Included in the Analysis

\begin{tabular}{ccccccc}
\hline Austria & Belgium & Bulgaria & Crotia & G.A.S.C. & Czechia & Denmark \\
Estonia & Finland & France & Germany & Greece & Hungary & Ireland \\
Italy & Latvia & Lithuania & Luxemburg & Malta & Netherland & Poland \\
Portugal & Romania & Slovakia & Slovenia & Spain & Sweden & UK \\
\hline
\end{tabular}

Table 5

Data Definition and Sources

\begin{tabular}{lll}
\hline Variable & Abbreviation & Data Source \\
\hline HDI index & HDI & UNDP \\
NEET \% & NEET & OECD Database \\
Unemployment \% & UNE & OECD Database \\
Education index & EDU & World Bank \\
\hline
\end{tabular}


The model examined within the scope of this research is shown in closed form as follows:

$$
H D I=f(U N E, N E E T, E D U)
$$

If the regression model is in open form, it is as follows:

$$
\ln H D I_{i t}=\alpha_{0 i}+\beta_{1 i} \ln U N E_{i t}+\beta_{2 i} \ln N E E T_{i t}+\beta_{3 i} \ln E D U_{i t}+\varepsilon_{i t}
$$

The dependent variable in Equation 2 is the Human Development Index (HDI), and the independent variables are: unemployment rate (UNE), the people who are not in education and non-employment segment (NEET), and the education index (EDU).

\section{Methodology}

\section{Panel Data Analysis}

In panel data analysis, just like in time series analysis, it is crucial to have information about the stationarity of variables in terms of reliability of the analysis. However, when analyzing panel data, unlike time series, the concepts of correlation / cross-sectional dependency and slope homogeneity/heterogeneity become essential and are investigated with various tests according to the structure of the panel.

The literature divides the panel unit root tests into first and second generation panel unit root tests. The first generation panel unit root tests can be defined as the interaction between the sections that make up the panel and does not take into account the cross-dependency between units. Thus, they are applied when it is observed that there is no cross-dependency between the units. The second generation panel unit root tests take into account the inter-unit correlation. As the first generation tests do not take into account the inter-unit correlation problem, they cannot provide reliable results if this problem exists. Also, Baltagi, Feng, and Kao (2012) state that if there is a correlation between units, traditional $t$ and $\mathrm{F}$ tests may become invalid and may even lead to inconsistent estimates. In this context, the first stage in the panel time series starts by testing the correlation between the units and continues with the appropriate panel unit root test selection.

Another concept named slope heterogeneity is specific to panel time series is, which indicates that each section that forms the panel has its own and 
statistically significant parameters. Maddala, Trost, Li, and Joutz (1997) state that estimating heterogeneous panels under the homogeneity assumption causes "heterogeneity deviation". For this reason, correlation and slope homogeneity between units should be tested, and appropriate panel unit root tests and estimators should be selected in accordance with the results obtained.

According to the study's data structure, since the cross-sectional dimension $(\mathrm{N})$ is larger than the time dimension (T) in the model (28>15), it shows a balanced and short panel feature. According to Pesaran's (2004) CD test results, the correlation problem between units was found in all variables firstly. For this reason, Cross-section Im, Pesaran, and Shin (CIPS) tests were preferred among the second generation panel unit root tests that work with the assumption of inter-unit correlation (Pesaran, 2007). Pesaran CIPS test results revealed that all variables are stable at level, in other words, they follow the I ( 0$)$ process. Since the Swamy test, which tests the slope homogeneity in the model, shows that the slopes / parameters are heterogeneous, an estimator with the assumption of parameter heterogeneity should be selected at the estimator selection stage. Therefore, the appropriate estimator has to assume the inter-unit correlation and slope heterogeneity. Estimator alternatives include Pesaran (2006) Common Correlated Effects (CCE), and Eberhardt and Teal (2010) Augmented Mean Group (AMG) estimators. For this reason, the relationships between variables are revealed using panel regression analysis using CCEMG and AMG estimators.

\section{Cross-Section Dependency(CD) Test}

Pesaran (2004) proposes an inter-unit correlation test on the short panels with $\mathrm{N}$ (cross-section) large and $\mathrm{T}$ (time) small features, which can be used in the analysis of various panels, including heterogeneous parameters (slope) or panels with unit-roots.

The test statistic of Pesaran (2004)'s CD test, where the null hypothesis is $H_{0}: \rho_{i j}=0$, is calculated as follows;

$$
C D=\sqrt{\frac{2 T}{N(N-1)}\left(\sum_{i=1}^{N-1} \sum_{j=i+1}^{N} \hat{\rho}_{i j}\right)}
$$


In equation (3), $\rho_{i j}: i, j$ indicates the correlation coefficient of the residual and estimated as follows;

$$
\left.\hat{\rho}_{i j}=\sum_{t=1}^{T} e_{i t} e_{j t} /\left(\sum_{t=1}^{T} e_{i t}^{2}\right)^{1 / 2} \sum_{t=1}^{T} e_{j t}^{2}\right)^{1 / 2}
$$

In equation (4), denotes the Least Squares (OLS) residuals. Monte Carlo simulations indicated that Pesaran (2004)'s CD test performed quite well in short panels where N is big, and T is small, unlike the Breusch-Pagan (1980)'s LM test (Baltagi, 2008: 284).

\section{Cross-section Im, Pesaran ve Shin (CIPS) Panel Unit Root Test}

Cross-section Im, Pesaran, and Shin (CIPS) panel unit root test developed by Pesaran (2007) is based on the modelling logic of inter-unit correlation through factors.

Pesaran (2007) extended the Augmented Dickey-Fuller (ADF) regression with the cross-sectional averages and lagged values of the series, and suggested that inter-unit correlation disappeared by taking the first-degree difference of the related regression.

CIPS statistics are the average of the CADF statistics obtained from extended ADFs and is estimated as follows in equation.5;

$$
\operatorname{CIPS}(N, T)=N^{-1} \sum_{t=1}^{N} t_{i}(N, T)
$$

The discrete type of CIPS statistics is shown in equation.6.

$$
\operatorname{CIPS}^{*}(N, T)=N^{-1} \sum_{i=1}^{N} t_{i}^{*}(N, T)
$$

The strongest aspect of the CIPS test is that it also performs well in small samples (Pesaran, 2007: 277). 


\section{Parameter Homogenity and Swamy Test}

Swamy (1970) carried out the first researches for testing slope/parameter homogeneity-heterogeneity in the panel data analysis. To test the random-effects model (RCM), Swamy (1970) ignored the panel-specific structure of a panel dataset, examined each section with OLS, and then observed the difference between the fixed effects estimator. Swamy (1970) revealed that a panel data analysis performed by ignoring the possible heterogeneity of the regression coefficient vector in a model might lead to biased estimates.

The null hypothesis of Swamy's slope homogeneity test is formed as H0: $\beta \mathrm{i}$ $=\beta$ and $\beta \mathrm{i}$ indicates that the coefficient vectors are constant; in other words, they are homogeneous. The test statistics are shown in equation.7.

$$
\hat{S}=X_{k(N-1)}^{2}=\sum_{i=1}^{N}\left(\hat{\beta}_{i}-\bar{\beta}^{*}\right)^{\prime} \hat{V}_{i}^{-1}\left(\hat{\beta}_{i}-\bar{\beta}^{*}\right)
$$

In equation. $5, \hat{\beta}$ indicates the OLS estimators derived from the regressions specific to the cross-sections, $\bar{\beta}^{*}$ Weigthed fixed effects estimator, and $\hat{V}_{i}$ indicates the variance difference of these estimators (Pesaran and Yamagata, 2008: 54).

Pesaran (2006) Common Correlated Effects Mean Group (CCEMG) Model Common Correlated E_ects Mean Group Model (CCEMG) proposed by Pesaran (2006) and assume a simple regressor. For all $\mathrm{i}=1,,,,,,,, \mathrm{~N}$ and all $\mathrm{t}$ $=1,,,,, \mathrm{~T}$,

$$
\begin{aligned}
& y_{i, t}=\beta_{i}^{\prime} x_{i, t}+u_{i, t} \\
& u_{i, t}=\alpha_{1 t}+\lambda_{i} f_{t}+\varepsilon_{i, t} \\
& x_{i, t}=\alpha_{2 i}+\lambda_{i} f_{t}+\gamma_{i} g_{t}+v_{i, t}
\end{aligned}
$$

$\mathrm{f}_{\mathrm{t}}$ and $\mathrm{g}_{\mathrm{t}}$ symbolizes the unobservable time-variant common factors with country-specific factor loadings $\lambda_{i}, \gamma_{i}, \alpha_{i}$ and $\alpha_{21}$ are country-specific fixed effects; and $\varepsilon_{i, t}$ and $v_{i, t}$ id iid errors with mean zero and finite variances. $\mathrm{ft}$ and gt causes the cross-section dependence in errors and regressors. 
The CCEMG model assumes that the common factors are like as nuisance parameters. This model finds a solution the cross-section dependence with taking into account the averages of regressors in all cross-section and all dependent variable. Peseran (2006) demonstrated that these means are liable for unobserved common factors. Differentiated impact of common factors are analyzed by calculating individual equations and finding themean of each factor loadings (Hernandez, 2015:12-13).

\section{Augmented Mean Group (AMG) Model}

There are many estimators in the literature to predict panel data models. This estimator, developed by Eberhardt and Teal (2010) and Bond and Eberhardt (2009), is used to predict panel data and is based on the assumption of interunit correlation and parameter heterogeneity (Eberhardt and Teal, 2010: 6). AMG estimator develops the CCEMG's complicated estimation about slope parameters of regressors and the averages, and AMG takes into account common dynamic process instead of unobserved common factors as nuisance in CCEMG. The model based on the Average Mean Group estimator is shown in equation.11.

$$
\Delta y_{i t}=b^{\prime} \Delta x_{i t}+\sum_{t=2}^{T} c_{t} \Delta D_{t}+e_{i t}=\widehat{c_{t}} \equiv \hat{\mu}_{t}^{*}
$$

Equation 12 is expanded with the first differences in pooled regression (T-1) time dummy variable and coefficients are estimated.

$$
y_{i t}=a_{i}+b_{i}^{\prime} x_{i t}+c_{i t}+d_{i} \hat{\mu}_{t}^{*}+e_{i t}
$$

$\hat{\mu}_{t}^{*}$, It takes place in the regression of each unit and models with the following equation.13 are estimated.

$$
\hat{b}_{A M G}=N^{-1} \sum_{i} \hat{b}_{i}
$$

Finally, the Average Mean Group Estimator has been combined under the Pesaran and Smith (1995)'s Average Group (MG) technique. Eberhardt and Bond (2009) found that this estimator works very well, especially in heterogeneous macro panels that correlate between units with their Monte Carlo studies (Eberhardt and Bond, 2009: 3). 


\section{Empirical Findings}

Table 6 shows the descriptive statistics regarding the variables examined within the scope of the study. According to descriptive statistics, the panel dataset performs as balanced and short panel $(\mathrm{N}(28)>\mathrm{T}(15))$.

Table 6

Descriptive Statistics

\begin{tabular}{lccccccc}
\hline \multicolumn{7}{l}{ Descriptive Statistics for Variables } \\
\hline Variables & N & T & Obs. & Mean & St. Dev. & Min. & Max. \\
\hline HDI & 28 & 15 & 420 & 0.8592905 & 0.0470938 & 0.685 & 0.942 \\
UNE & 28 & 15 & 420 & 8.750447 & 4.274902 & 2.243518 & 27.46715 \\
NEET & 28 & 15 & 420 & 11.46983 & 4.310643 & 3.62 & 25.05 \\
EDU & 28 & 15 & 420 & 0.8283071 & 0.0596472 & 0.673 & 0.946 \\
\hline
\end{tabular}

Correlation, stationarity and heterogeneity between units should be tested before the prediction phase of the panel regression model.

Since the panel data set examined within the scope of this study exhibits an N> $\mathrm{T}$ feature, the correlation between the units in the variables and the model was evaluated using Pesaran (2004)'s CD test, the unit root presence in the variables using Pesaran (2007)'s CIPS panel unit root test and the slope homogeneity of Swamy (1970)'s test and Pesaran and Yamagata (2008)'s Delta test.

Table 7

Pesaran (2004) CD Test

\begin{tabular}{lcc}
\hline \multicolumn{2}{l}{ Pesaran (2004) Cross-sectional Dependence Test (for variables) } \\
\hline Variables & CD Test Stat. & p-Value \\
\hline HDI & 71.19 & $0.000^{*}$ \\
UNE & 26.75 & $0.000^{*}$ \\
NEET & 20.09 & $0.000^{*}$ \\
EDU & 63.12 & $0.000^{*}$ \\
\hline
\end{tabular}

Note: $* * * * * *$ denote the significance levels of alpha at $0.01,0.05$, and 0.10 respectively.

Table 7 shows the results of Pesaran (2004)'s CD test for testing the correlation between the variables in the units. The results revealed that there is a correlation between the units in all variables. Since the results from Table 7 shows a crosssectional dependence, we need to apply a second generation panel unit root test. This is due to the fact that second generation panel unit root tests can only be applied where there is a cross-sectional dependence. Among the second generation panel unit root tests, Pesaran (2007)'s Cross-section Im, Pesaran and Shin (CIPS) tests were preferred in the rest of this analysis. 
Table 8

Pesaran (2007) CIPS Panel Unit Root Test

Pesaran CIPS (2007) Panel Unit Root Test

\begin{tabular}{lcc}
\hline Variables & Intercept & Intercept and Trend \\
\hline HDI & $-2.673(0.004)^{*}$ & $-2.173(0.015)^{* *}$ \\
UNE & $-3.845(0.000)^{*}$ & $-1.519(0.064)^{* * *}$ \\
NEET & $-2.440(0.007)^{*}$ & $-3.085(0.001)^{*}$ \\
EDU & $-3.048(0.001)^{*}$ & $-1.595(0.055)^{* * *}$ \\
\hline
\end{tabular}

Note: $*, * *, * * *$ denote the significance levels of alpha at $0.01,0.05$, and 0.10 respectively.

Table 8 shows the Pesaran's CIPS test results to investigate the unit root presence in the variables. All variables were stationary at the level; in other words, I (0).

After this stage, the panel regression model, which will be examined within the scope of the research, will be tested to ascertain whether there is slope heterogeneity and cross-section dependency problem between the units, and the estimator will be selected based on the results.

Table 9

Slope Homogeneity Test

\begin{tabular}{lc}
\hline Swamy Slope Homogeneity Test & \\
\hline$\chi^{2}$ Stat. & 47903.63 \\
p-Value & $0.0000^{*}$ \\
\hline
\end{tabular}

Note: $* * *, * * *$ denote the significance levels of alpha at $0.01,0.05$, and 0.10 respectively.

The results of the Swamy slope homogeneity test in the model are presented in Table 9. According to the results, the null hypothesis, which states that the slopes/parameters are homogeneous, is rejected, and each section has its own statistically significant regression parameters. Thus, it is necessary to choose an estimator with the assumption of parameter heterogeneity in the estimator selection step.

Table 10

Pesaran CD Test

\begin{tabular}{lc}
\hline Pesaran CD (2004) Cross-Sectional Dependence Test (for model) \\
\hline$\chi^{2}$ Stat. & 5.33 \\
p-Value & $0.000^{*}$ \\
\hline Note: ${ }^{* * *, * * *}$ denote the significance levels of alpha at $0.01,0.05$, and 0.10 respectively.
\end{tabular}

Table 10 shows the results of Pesaran (2004)'s CD test to analyze the correlation between units in the model. According to the results, there is a correlation between units in the model. 
According to the results obtained from Table 9 and Table 10, there is slope heterogeneity and a correlation between units in the regression model examined. In light of these results, the appropriate estimator should assume a correlation between units and slope heterogeneity. Estimator possibilities include Pesaran (2006)'s Common Correlated Effects (CCE) and Eberhardt and Teal (2010)'s Augmented Mean Group (AMG) estimators. The model estimated with both estimators is presented below.

Table 11

Pesaran (2006) Common Correlated Effects Mean Group (CCEMG) Estimator

\begin{tabular}{|c|c|c|c|c|c|}
\hline \multicolumn{6}{|c|}{ Pesaran (2006) Common Correlated Effects Mean Group (CCEMG) Estimator (for panel) } \\
\hline \multicolumn{6}{|c|}{ Dependence Variable HDI } \\
\hline Regressors & & Coefficient & Std. Err. & z Stat. & p-Value \\
\hline Cons. & & 0.000674 & 0.007139 & 0.09 & 0.925 \\
\hline UNE & & -0.0100931 & 0.002134 & -4.73 & $0.000 *$ \\
\hline NEET & & -0.0002808 & 0.001824 & -0.15 & 0.878 \\
\hline EDU & & 0.3003286 & 0.016019 & 18.75 & $0.000 *$ \\
\hline $\begin{array}{l}\text { Wald } \chi^{2} \text { Stat. } \\
\text { p-Value }\left(\chi^{2}\right) \\
\text { RMSE }\end{array}$ & $\begin{array}{c}447.50 \\
0.0000^{*} \\
0.0009\end{array}$ & & & & \\
\hline
\end{tabular}

Note: $* * *, * * *$ denote the significance levels of alpha at $0.01,0.05$, and 0.10 respectively.

Table 11 shows the results of the regression estimation on a panel basis with the CCEMG estimator. The results show that UNE and EDU variables are statistically significant in explaining HDI throughout the panel, while the NEET variable is not statistically significant, but it can also be seen that the coefficient trends in the expected direction. In this case, a 1\% increase in UNE variable decreases HDI by $0.01 \%$, while a $1 \%$ increase in EDU variable increases HDI by $0.30 \%$. The model appears to be statistically significant. It was also noted that the RMSE value is 0.0009 .

Table 12

Eberhardt and Teal (2010) Augmented Mean Group (AMG) Estimator

\begin{tabular}{lcccc}
\hline \multicolumn{4}{l}{ Eberhardt and Teal (2010) Augmented Mean Group (AMG) Estimator (for panel) } \\
\hline Dependence Variable HDI & \multicolumn{4}{l}{} \\
\hline Regressors & Coefficient & Std. Err. & z Stat. & p-Value \\
\hline Cons. & -0.09333 & 0.012461 & -7.49 & $0.000^{*}$ \\
UNE & -0.00606 & 0.0020681 & -2.93 & $0.003^{*}$ \\
NEET & -0.00282 & 0.0021628 & -1.31 & 0.192 \\
EDU & 0.323225 & 0.0147615 & 21.9 & $0.000^{*}$ \\
\hline
\end{tabular}

Note: $* * *, * * *$ denote the significance levels of alpha at $0.01,0.05$, and 0.10 respectively.

Table 12 shows the regression estimation results based on a panel using the AMG estimator. The results indicate that UNE and EDU variables are statistically 
significant in explaining HDI throughout the panel, while the NEET variable is not statistically significant.

After this step, the regression estimation was made on the basis of units of the model, which was estimated with the CCEMG estimator, where the RMSE value was lower.

Table 13

Pesaran (2006) Common Correlated Effects (CCE) Estimator

\begin{tabular}{|c|c|c|c|c|c|}
\hline \multicolumn{6}{|c|}{ Pesaran (2006) Common Correlated Effects (CCE) Estimator (for groups/countries) } \\
\hline Groups & Variables & Coefficient & Std. Err. & z Stat. & p-Value \\
\hline \multirow[t]{4}{*}{ Austria } & Cons. & 0.000107 & 0.011384 & 0.01 & 0.992 \\
\hline & UNE & -0.00961 & 0.002914 & -3.3 & $0.001 *$ \\
\hline & NEET & -0.00514 & 0.003962 & -1.3 & 0.194 \\
\hline & EDU & 0.341987 & 0.014688 & 23.28 & $0.000^{*}$ \\
\hline \multirow[t]{4}{*}{ Belgium } & Cons. & 0.009404 & 0.010823 & 0.87 & 0.385 \\
\hline & UNE & -0.00475 & 0.004955 & -0.96 & 0.337 \\
\hline & NEET & 0.002936 & 0.003027 & 0.97 & 0.332 \\
\hline & EDU & 0.240642 & 0.08306 & 2.9 & $0.004^{*}$ \\
\hline \multirow[t]{4}{*}{ Bulgaria } & Cons. & -0.06211 & 0.020391 & -3.05 & $0.002 *$ \\
\hline & UNE & -0.0138 & 0.006102 & -2.26 & $0.024 * *$ \\
\hline & NEET & -0.00293 & 0.015899 & -0.18 & 0.854 \\
\hline & EDU & 0.27539 & 0.045712 & 6.02 & $0.000 *$ \\
\hline \multirow[t]{4}{*}{ Crotia } & Cons. & -0.02093 & 0.010723 & -1.95 & $0.051 * *$ \\
\hline & UNE & 0.001487 & 0.004232 & 0.35 & 0.725 \\
\hline & NEET & -0.00991 & 0.007164 & -1.38 & 0.166 \\
\hline & EDU & 0.312228 & 0.060859 & 5.13 & $0.000^{*}$ \\
\hline \multirow[t]{4}{*}{ G.A.S.C. } & Cons. & -0.00481 & 0.025243 & -0.19 & 0.849 \\
\hline & UNE & -0.01283 & 0.002596 & -4.94 & $0.000^{*}$ \\
\hline & NEET & 0.005267 & 0.004862 & 1.08 & 0.279 \\
\hline & EDU & 0.3882 & 0.062855 & 6.18 & $0.000^{*}$ \\
\hline \multirow[t]{4}{*}{ Czech Rep. } & Cons. & -0.03197 & 0.027339 & -1.17 & 0.242 \\
\hline & UNE & -0.00171 & 0.004321 & -0.4 & 0.691 \\
\hline & NEET & -0.00721 & 0.003451 & -2.09 & $0.037 * *$ \\
\hline & EDU & 0.288999 & 0.103175 & 2.8 & $0.005 *$ \\
\hline \multirow[t]{4}{*}{ Denmark } & Cons. & 0.002236 & 0.007186 & 0.31 & 0.756 \\
\hline & UNE & -0.00409 & 0.002229 & -1.83 & $0.067 * *$ \\
\hline & NEET & -0.00381 & 0.00197 & -1.93 & $0.053 * *$ \\
\hline & EDU & 0.327052 & 0.016124 & 20.28 & $0.000^{*}$ \\
\hline \multirow[t]{4}{*}{ Estonia } & Cons. & -0.0025 & 0.011242 & -0.22 & 0.824 \\
\hline & UNE & -0.00825 & 0.002028 & -4.07 & $0.000^{*}$ \\
\hline & NEET & -0.00144 & 0.003457 & -0.42 & 0.676 \\
\hline & EDU & 0.240954 & 0.090655 & 2.66 & $0.008 *$ \\
\hline
\end{tabular}




\begin{tabular}{|c|c|c|c|c|c|}
\hline \multirow[t]{4}{*}{ Finland } & Cons. & 0.02834 & 0.008282 & 3.42 & $0.001 *$ \\
\hline & UNE & -0.00247 & 0.002862 & -0.86 & 0.387 \\
\hline & NEET & -0.00713 & 0.002748 & -2.59 & $0.009 *$ \\
\hline & EDU & 0.310798 & 0.018528 & 16.77 & $0.000 *$ \\
\hline \multirow[t]{4}{*}{ France } & Cons. & 0.024573 & 0.013171 & 1.87 & $0.062 * *$ \\
\hline & UNE & -0.010162 & 0.003297 & -3.08 & $0.002 *$ \\
\hline & NEET & 0.001302 & 0.003432 & 0.38 & 0.704 \\
\hline & EDU & 0.393137 & 0.045134 & 8.71 & $0.000^{*}$ \\
\hline \multirow[t]{4}{*}{ Germany } & Cons. & 0.019604 & 0.011807 & 1.66 & $0.097 * * *$ \\
\hline & UNE & 0.007354 & 0.002697 & 2.73 & $0.006^{*}$ \\
\hline & NEET & -0.00578 & 0.003439 & -1.68 & $0.093 * * *$ \\
\hline & EDU & 0.362379 & 0.047559 & 7.62 & $0.000 *$ \\
\hline \multirow[t]{4}{*}{ Greece } & Cons. & -0.03892 & 0.024748 & -1.57 & 0.116 \\
\hline & UNE & -0.00619 & 0.002938 & -2.11 & $0.035^{* *}$ \\
\hline & NEET & -0.0079 & 0.004921 & -1.61 & 0.108 \\
\hline & EDU & 0.335348 & 0.035523 & 9.44 & $0.000^{*}$ \\
\hline \multirow[t]{4}{*}{ Hungary } & Cons. & -0.03917 & 0.023386 & -1.68 & $0.094 * * *$ \\
\hline & UNE & -0.00947 & 0.00228 & -4.16 & $0.000 *$ \\
\hline & NEET & 0.003431 & 0.006055 & 0.57 & 0.571 \\
\hline & EDU & 0.375602 & 0.042696 & 8.8 & $0.000^{*}$ \\
\hline \multirow[t]{4}{*}{ Ireland } & Cons. & 0.083408 & 0.038968 & 2.14 & $0.032 * *$ \\
\hline & UNE & -0.01407 & 0.005037 & -2.79 & $0.005^{*}$ \\
\hline & NEET & 0.000457 & 0.009184 & 0.05 & 0.960 \\
\hline & EDU & 0.360309 & 0.096249 & 3.74 & $0.000^{*}$ \\
\hline \multirow[t]{4}{*}{ Italy } & Cons. & -0.00564 & 0.024365 & -0.23 & 0.817 \\
\hline & UNE & -0.00952 & 0.004383 & -2.17 & $0.030 * *$ \\
\hline & NEET & -0.00726 & 0.009687 & -0.75 & 0.454 \\
\hline & EDU & 0.256885 & 0.072388 & 3.55 & $0.000^{*}$ \\
\hline \multirow[t]{4}{*}{ Latvia } & Cons. & -0.04937 & 0.032227 & -1.53 & 0.126 \\
\hline & UNE & -0.00814 & 0.003437 & -2.37 & $0.018^{*}$ \\
\hline & NEET & 0.007995 & 0.005648 & 1.42 & 0.157 \\
\hline & EDU & 0.199937 & 0.194898 & 1.03 & 0.305 \\
\hline \multirow[t]{4}{*}{ Lithuania } & Cons. & 0.019212 & 0.043302 & 0.44 & 0.657 \\
\hline & UNE & -0.00363 & 0.007322 & -0.5 & 0.620 \\
\hline & NEET & -0.01057 & 0.014897 & -0.71 & 0.478 \\
\hline & EDU & 0.214345 & 0.102923 & 2.08 & $0.037 * *$ \\
\hline \multirow[t]{4}{*}{ Luxemburg } & Cons. & 0.01218 & 0.027089 & 0.45 & 0.653 \\
\hline & UNE & -0.00296 & 0.006541 & -0.45 & 0.651 \\
\hline & NEET & -0.00013 & 0.006311 & -0.02 & 0.984 \\
\hline & EDU & 0.206943 & 0.124484 & 1.66 & $0.096 * * *$ \\
\hline \multirow[t]{4}{*}{ Malta } & Cons. & 0.032617 & 0.023723 & 1.37 & 0.169 \\
\hline & UNE & -0.03664 & 0.010089 & -3.63 & $0.000 *$ \\
\hline & NEET & 0.010523 & 0.005088 & 2.07 & $0.039 * *$ \\
\hline & EDU & 0.372719 & 0.056685 & 6.58 & $0.000 *$ \\
\hline
\end{tabular}




\begin{tabular}{|c|c|c|c|c|c|}
\hline \multirow[t]{4}{*}{ Netherlands } & Cons. & 0.0117 & 0.016289 & 0.72 & 0.473 \\
\hline & UNE & -0.00735 & 0.002631 & -2.79 & $0.005^{*}$ \\
\hline & NEET & 0.003021 & 0.005472 & 0.55 & 0.581 \\
\hline & EDU & 0.392694 & 0.055093 & 7.13 & $0.000^{*}$ \\
\hline \multirow[t]{4}{*}{ Poland } & Cons. & -0.0593 & 0.022779 & -2.6 & $0.009 *$ \\
\hline & UNE & -0.0164 & 0.005441 & -3.01 & $0.003^{*}$ \\
\hline & NEET & 0.016936 & 0.009782 & 1.73 & $0.083 * * *$ \\
\hline & EDU & 0.374544 & 0.033433 & 11.2 & $0.000 *$ \\
\hline \multirow[t]{4}{*}{ Portugal } & Cons. & -0.02896 & 0.009457 & -3.06 & $0.002 *$ \\
\hline & UNE & -0.03013 & 0.009779 & -3.08 & $0.002 *$ \\
\hline & NEET & 0.034593 & 0.014457 & 2.39 & $0.017 * *$ \\
\hline & EDU & 0.240337 & 0.034222 & 7.02 & $0.000^{*}$ \\
\hline \multirow[t]{4}{*}{ Romania } & Cons. & 0.038899 & 0.021232 & 1.83 & $0.067 * * *$ \\
\hline & UNE & -0.02472 & 0.008197 & -3.02 & $0.003 *$ \\
\hline & NEET & -0.00854 & 0.007724 & -1.11 & 0.269 \\
\hline & EDU & 0.360742 & 0.0292 & 12.35 & $0.000^{*}$ \\
\hline \multirow[t]{4}{*}{ Slovak Rep. } & Cons. & 0.024112 & 0.018206 & 1.32 & 0.185 \\
\hline & UNE & -0.00544 & 0.007789 & -0.7 & 0.485 \\
\hline & NEET & -0.00761 & 0.008864 & -0.86 & 0.391 \\
\hline & EDU & 0.37437 & 0.044411 & 8.43 & $0.000^{*}$ \\
\hline \multirow[t]{4}{*}{ Slovenia } & Cons. & 0.008667 & 0.014933 & 0.58 & 0.562 \\
\hline & UNE & -0.01273 & 0.004923 & -2.59 & $0.010^{*}$ \\
\hline & NEET & -0.00202 & 0.005416 & -0.37 & 0.710 \\
\hline & EDU & 0.329141 & 0.068146 & 4.83 & $0.000^{*}$ \\
\hline \multirow[t]{4}{*}{ Spain } & Cons. & -0.01437 & 0.015418 & -0.93 & 0.351 \\
\hline & UNE & 0.003017 & 0.003978 & 0.76 & 0.448 \\
\hline & NEET & -0.00537 & 0.004218 & -1.27 & 0.203 \\
\hline & EDU & 0.190111 & 0.156861 & 1.21 & 0.226 \\
\hline \multirow[t]{4}{*}{ Sweden } & Cons. & -0.03414 & 0.051996 & -0.66 & 0.511 \\
\hline & UNE & 0.001589 & 0.008567 & 0.19 & 0.853 \\
\hline & NEET & -0.00858 & 0.010101 & -0.85 & 0.396 \\
\hline & EDU & 0.324394 & 0.016955 & 19.13 & $0.000 *$ \\
\hline \multirow[t]{4}{*}{ UK } & Cons. & 0.096015 & 0.047184 & 2.03 & $0.042 * *$ \\
\hline & UNE & -0.041 & 0.021425 & -1.91 & $0.056 * * *$ \\
\hline & NEET & 0.007017 & 0.018102 & 0.39 & 0.698 \\
\hline & EDU & 0.019017 & 0.120793 & 0.16 & 0.875 \\
\hline
\end{tabular}

Note: $* * *, * * *$ denote the significance levels of alpha at $0.01,0.05$, and 0.10 respectively.

Table 13 shows the regression estimation results based on units (according to each country). It should be noted that although the coefficients vary quantitatively and statistically, the NEET variable, which is meaningless throughout the panel, varies statistically from unit to unit. NEET and HDI are negatively related in Czechia (5\%), Denmark (5\%), Finland (1\%), and Germany 
$(10 \%)$, while they are positively correlated in France (1\%), Poland (10\%) and Portugal (10\%).

According to Pesaran (2006) Common Correlated Effects (CCE) Estimator findings in Table 13, a positive relationship was found between HDI and education, and a negative relationship between unemployment and HDI in the majority of EU countries. The findings are as follows;

There is a positive relationship between Education and HDI in $22 \mathrm{EU}$ countries. These countries are Austria, Belgium, Bulgaria, Croatia, GASC, Czech Republic, Denmark, Estonia, Finland, France, Greece, Hungary, Ireland, Italy, Lithuania, Luxembourg, Malta, Netherlands, Poland, Portugal, Slovakia, Slovenia and Sweden.

In $16 \mathrm{EU}$ countries, a negative relationship was found between unemployment and HDI. These countries are; Austria, Bulgaria, Croatia, GASC, Denmark, Estonia, Greece, Hungary, Ireland, Italy, Latvia, Netherlands, Poland, Portugal, Romania, Slovenia, England. Despite these results, it has been revealed that there is a positive relationship between unemployment and HDI in Germany.

Countries with a positive relationship between NEET and HDI are Malta, Poland and Portugal, while countries with a negative relationship are Czech rep. Denmark, Finland, Germany.

\section{Conclusion}

When examining the relationship between economic growth and development, monetary criteria such as per capita income as a popular indicator of development, etc. were used until the 1990s. However, it is now understood that financial criteria alone are not sufficient in measuring human development. For this reason, the United Nations Development Program (UNDP) has started to publish human development reports reflecting the socioeconomic projections of the world's countries since 1990. Although the relationship between economic growth and employment-unemployment is frequently studied in the literature, the relationship between human development index components as one of the indicators of socioeconomic development, employment-unemployment and Not in Education, Employment, or Training (NEET) prevalence has not been studied yet. For this purpose, this study plans to present the impact of unemployment, education, and NEET on human development on EU 28 countries empirically. 
This study aims to reveal the effect of education, unemployment, and NEET prevalence on human development in the EU-28 countries during the 20002018 period by using panel data analysis in order to Show how macroeconomic variables other than economic growth may be correlated with human development in a zone with different kinds of welfare models. According to the results of a regression analysis run on the panel using the CCEMG estimator, UNE and EDU variables are statistically significant in explaining HDI across the panel. In contrast, the NEET variable doesn't appear to be statistically significant, despite the coefficient obtained being in the expected direction. In this case, a $1 \%$ increase in the UNE variable causes a $0.01 \%$ decrease in HDI, and a $1 \%$ increase in the EDU variable causes a $0.30 \%$ increase. The model appears to be statistically significant.

In the panel analysis, different country groups show different results: while Mediterranean countries show positive correlation, Scandinavian countries behave differently. In this scenario, NEET problem has a relatively low-profile impact on northern countries with well-established welfare models, whereas in countries with a southern European or mediterranean welfare model, the problem has an adverse impact.

The regression estimation results are based on units (for each country), while the coefficients vary quantitatively and statistically. Still, it is noteworthy that the NEET variable, which is meaningless throughout the panel, varies statistically from unit to unit. NEET and HDI are negatively correlated in Czechia (5\%), Denmark (5\%), Finland (1\%), and Germany (10\%), while positively correlated in France (1\%), Poland (10\%), and Portugal (10\%).

It is essential to identify the determinants of HDI, which has become one of the most prominent indicators used in measuring the development of a society. To our knowledge, there are no studies empirically testing the determinants of HDI. Generally, the relationship between HDI and economic growth is discussed in the literature. However, its relationship with variables that affect human capital, such as the unemployment rate, education, etc. has been neglected. Therefore, empirical presentation of the determinants of HDI with this study will contribute to the literature. In addition, the fact that this study was carried out on the EU-28, most successful economic union in the world, will enable inference on a global scale. CCEMG and AMG test results verified that there is a negative relationship between unemployment and HDI, whereas there is a positive relationship between 
education index and HDI. These findings suggest that policymakers should take into account unemployment rate and education levels in order to encourage development and raise the living standards of their societies. It is vital to prioritize unemployment-reducing government policies while increasing the level of education for more welfare and more comfortable lives.

Peer-review: Externally peer-reviewed.

Conflict of Interest: The author has no conflict of interest to declare.

Grant Support: The author declared that this study has received no financial support. 


\section{References}

Aturupane, H., Glewwe, P., \& Isenman, P. (1994). Poverty, Human Development and Growth: An Emerging Consensus?. American Economic Review, Papers and Proceedings, 84(2), pp. 244-249.

Aydin, M. (2019). İnsani Gelişme ve Ekonomik Büyüme İlişkisi: Türkiye Üzerine Ampirik Bir Çalı̧̧ma. Research Journal of Politics, Economics and Management, 7, 33-43.

Baltagi, B. (2008). Econometric Analysis of Panel Data (4th ed.). Hoboken, NJ: John Wiley \& Sons.

Baltagi, B. H., Feng, Q. \& Kao, C. (2012). A Lagrange Multiplier Test for Cross-Sectional Dependence in a Fixed Effects Panel Data Model. Journal of Econometrics, 170(1), 164-177.

Breusch, T. \& Pagan, A. (1980). The Lagrange Multiplier Test and Its Applications to Model Specification in Econometrics. Review of Economic Studies, 47, 239-253.

Bynner, J., \& Parsons, S. (2002). Social exclusion and the transition from school to work: The case of young people not in education, employment, or training (NEET). Journal of Vocational Behavior, 60(2), 289-309. https://doi.org/10.1006/jvbe.2001.1868

Balc1, E., \& Özcan, S. (2019). İnsani Gelişmişlik ve Büyüme Arasındaki İlişki: OIC Ülkeleri Üzerinde Bir Analiz. Sakarya İktisat Dergisi, 8(3), 222-235.

Camp, S. L. \& J. J. Speidel (1987). The International Human Suffering Index, Washington: Population Crisis Committee.

Côté, J. E. (1997). An empirical test of the identity capital model. Journal of Adolescence, 20(5), 577-597.

Eberhardt, M., \& Bond, S. (2009). Cross-Section Dependence in Nonstationary Panel Models: A Novel Estimator. MPRA WP 17870.

Eberhardt, M., \& Teal, F. (2010). Productivity Analysis in Global Manufacturing Production. Economics Series Working Papers 515. University of Oxford, Department of Economics.

Erdem, E., \& Çelik, B. (2019). İnsani Gelişme ve Ekonomik Büyüme İlişkisi: Bazı Afrika Ülkeleri Üzerine Bir Uygulama. Bingöl Üniversitesi Sosyal Bilimler Enstitüsü Dergisi, 9(17), pp.13-36

Feng, Y., Lagakos, D., \& Rauch, J. E. (2018). Unemployment and development (No. w25171). Working Paper, National Bureau of Economic Research.

Flores-Crespo, P. (2007). Education, employment and human development: illustrations from Mexico. Journal of Education and Work, 20(1), 45-66. DOI: $10.1080 / 13639080601143120$

Haq, M. (1995). The Advent of the Human Development Report. Reflections on Human Development. Oxford University Press. UK.

Hernández, Marco A. (2015). Estimating Capital Flows to Emerging Market Economies With Heterogeneous Panels, Working Papers, No. 2015-03, Banco de México, Ciudad de México. 
Hull, K. (2009). Understanding the Relationship between Economic Growth, Employment and Poverty Reduction. Promoting Pro-Poor Growth: Employment. OECD Working Paper. pp. 69-93.

Im, K., Pesaran, M. H., \& Shin, Y. (2003). Testing for Unit Roots in Heterogeneous Panels. Journal of Econometrics, 115, 53-74.

Karnani, A. (2009). Reducing Poverty Through Employment. Innovations: Technology, Governance, Globalization, 6(2), 73-97. https://doi.org/10.1162/INOV_a_00071

Kelley, A. (1989). The "International Human Suffering Index": Reconsideration of the Evidence. Population and Development Review, 15(4), 731-737. doi:10.2307/1972597

Keskin, A. (2011). Ekonomik Kalkınmada Beşeri Sermayenin Rolü ve Türkiye. Atatürk Üniversitesi İktisadi ve İdari Bilimler Dergisi, 25(3-4), 125-153.

Maddala, G. S., Trost, R.P. , Li, H., \& Joutz, F. (1997). Estimation of Short-Run and LongRun Elasticities of Energy Demand from Panel Data Using Shrinkage Estimators. Journal of Business \& Economic Statistics, 15(1), 90-100.

Morris, M. D. (1979). Measuring the condition of the world's poor: The physical qualityof-life index. New York: Pergamon Press for the Overseas Development Council.

Quintano, C., Mazzocchi, P. \& Rocca, A. (2018). The determinants of Italian NEETs and the Effects Of The Economic Crisis, Genus, 74(5). https://doi.org/10.1186/s41118-018-0031-0

OECD (2014). OECD Better Life Index Executive Summary http://www. oecdbetterlifeindex.org/media/bli/documents/BLI_executive_summary_2014.pdf (Date of access: 13/02/2020).

Pesaran, M. H., \& Smith, R. (1995). Estimating Long-run Relationships from Dynamic Heterogeneous Panels. Journal of Econometrics, 68(1), 79-113.

Pesaran, M. H. (2004). General Diagnostic Tests for Cross Section Dependence in Panels. University of Cambridge, Faculty of Economics. Cambridge WP 0435 in Economics.

Pesaran, M. H. (2006). Estimation and Inference in Large Heterogeneous Panels with Multifactor Error Structure. Econometrica, 74, 967-1012.

Pesaran, M. H. (2007). A Simple Panel Unit Root Test in the Presence of Cross Sectional Dependence. Journal of Applied Econometrics, 22(2), 265-312.

Pesaran, M. H., \& Yamagata, T. (2008). Testing Slope Homogeneity in Large Panels. Journal of Econometrics, 142(1), 50-93.

Ranis, G., Stewart, F., \& Ramirez, A. (2000). Economic growth and human development. World development, 28(2), 197-219.

Sen, A. (1999). Development as freedom. Oxford: Oxford University Press

Stanton, E. A. (2007). "The Human Development Index: A History," Working Papers wp127, Political Economy Research Institute, University of Massachusetts at Amherst.

Suri, T., Boozer, M. A., Ranis, G., \& Stewart, F. (2010). Paths to Success: The Relationship Between Human Development and Economic Growth. World Development, 39(4), pp. 506-522. 
Swamy, P. A. (1970). Efficient Inference in a Random Coefficient Regression Model. Econometrica, 38(2), 311-323.

Taner, M., Sezen, B., \& Mihc1, H. (2011). “An Alternative Human Development Index Considering Unemployment," South East European Journal of Economics and Business, Sciendo, 6(1), 45-60.

Uğur, M. S. (2017). Amartya Sen'in Kapasite Yaklaşımı ve İnsan Merkezli Bir Kalkınma Anlayışı, Sosyoekonomi, 25(31), 91-107.

Ulas, E., \& Keskin, B. (2017). Is There a Relation Between HDI and Economic Performances? New Trends in Finance and Accounting Proceedings of the 17th Annual Conference on Finance and Accounting. Ed. Procházka, D., pp. 61-70.

UNDP (2009). 2009 Human Development Report http://www.hdr.undp.org/sites/default/ files/reports/269/hdr_2009_en_complete.pdf (Date of access: 13/02/2020).

UNDP (2010). 2010 Human Development Report http://hdr.undp.org/sites/default/files/ reports/270/hdr_2010_en_complete_reprint.pdf (Date of access: 13/02/2020).

UNDP (2019). 2019 Human Development Index Ranking, http:/hdr.undp.org/en/ content/2019-human-development-index-ranking (Date of Access:13/02/2020).

Zanbak, M., \& Kartal, A. (2019). “İnsani Gelişme Endeksi ile Kadın İşsizliği Arasındaki İlişki: BRICS-TM Ülkelerine Yönelik Ekonometrik Bir Analiz”, INES-2019 Proceedings, pp. 450-457. 